University of Nebraska - Lincoln

DigitalCommons@University of Nebraska - Lincoln

\title{
Field-Scale Cleanup of Atrazine and Cyanazine Contaminated Soil with a Combined Chemical-Biological Approach
}

\author{
Manmeet Waria \\ University of Nebraska - Lincoln \\ Steven Comfort \\ University of Nebraska - Lincoln, scomfort1@unl.edu \\ Sathaporn Onanong \\ University of Nebraska - Lincoln, sonanong2@unl.edu \\ T. Satapanajaru \\ Kasetsart University \\ Hardiljeet Boparai \\ University of Nebraska - Lincoln \\ See next page for additional authors
}

Follow this and additional works at: https://digitalcommons.unl.edu/watercenterpubs

Part of the Water Resource Management Commons

Waria, Manmeet; Comfort, Steven; Onanong, Sathaporn; Satapanajaru, T.; Boparai, Hardiljeet; Harris, C.; Snow, Daniel D.; and Cassada, David A., "Field-Scale Cleanup of Atrazine and Cyanazine Contaminated Soil with a Combined Chemical-Biological Approach" (2009). Faculty Publications from The Water Center. 15. https://digitalcommons.unl.edu/watercenterpubs/15

This Article is brought to you for free and open access by the Water Center, The at DigitalCommons@University of Nebraska - Lincoln. It has been accepted for inclusion in Faculty Publications from The Water Center by an authorized administrator of DigitalCommons@University of Nebraska - Lincoln. 
Authors

Manmeet Waria, Steven Comfort, Sathaporn Onanong, T. Satapanajaru, Hardiljeet Boparai, C. Harris, Daniel D. Snow, and David A. Cassada 


\title{
Field-Scale Cleanup of Atrazine and Cyanazine Contaminated Soil with a Combined Chemical-Biological Approach
}

\author{
M. Waria, S. D. Comfort, * and S. Onanong University of Nebraska-Lincoln \\ T. Satapanajaru Kasetsart University \\ H. Boparai University of Nebraska-Lincoln \\ C. Harris Albion College \\ D. D. Snow and D. A. Cassada University of Nebraska-Lincoln
}

A former agrichemical dealership in western Nebraska was suspected of having contaminated soil. Our objective was to characterize and remediate the contaminated site by a combined chemical-biological approach. This was accomplished by creating contour maps of the on-site contamination, placing the top $60 \mathrm{~cm}$ of contaminated soil in windrows and mixing with a mechanical high-speed mixer. Homogenized soil containing both atrazine [6-chloro- $N$-ethyl- $N$-isopropyl-1,3,5-triazine2,4-diamine] and cyanazine $\{2$-[[4-chloro-6-(ethylamino)-1,3,5triazin-2-yl] amino]-2-methylpropanenitrile\} was then used in laboratory investigations to determine optimum treatments for pesticide destruction. Iron suspension experiments verified that zerovalent iron $\left(\mathrm{Fe}^{0}\right)$ plus ferrous sulfate $\left(\mathrm{FeSO}_{4} \cdot 7 \mathrm{H}_{2} \mathrm{O}\right)$ removed more than $90 \%$ of both atrazine and cyanazine within $14 \mathrm{~d}$. Liquid chromatography/mass spectrometry (LC/ MS) analysis of the atrazine solution after treating with $\mathrm{Fe}^{0}$ and ferrous sulfate identified several degradation products commonly associated with biodegradation (i.e., deethlyatrazine (DEA), deisopropylatrazine (DIA), hydroxyatrazine (HA), and ammelines). Biological treatment evaluated emulsified soybean [Glycine max (L.) Merr.] oil (EOS) as a carbon source to stimulate biodegradation in static soil microcosms. Combining emulsified soybean oil with the chemical amendments resulted in higher destruction efficiencies $(80-85 \%)$ and reduced the percentage of $\mathrm{FeSO}_{4}$ needed. This chemical-biological treatment $\left(\mathrm{Fe}^{0}+\mathrm{FeSO}_{4}\right.$ + EOS, EOS Remediation, Raleigh, NC) was then applied with water to $275 \mathrm{~m}^{3}$ of contaminated soil in the field. Windrows were tightly covered with clear plastic to increase soil temperature and maintain soil water content. Temporal sampling (0-342 d) revealed atrazine and cyanazine concentrations decreased by 79 to $91 \%$. These results provide evidence that a combined chemicalbiological approach can be used for on-site, field-scale treatment of pesticide-contaminated soil.

Copyright $\odot 2009$ by the American Society of Agronomy, Crop Science Society of America, and Soil Science Society of America. All rights reserved. No part of this periodical may be reproduced or transmitted in any form or by any means, electronic or mechanical, including photocopying, recording, or any information storage and retrieval system, without permission in writing from the publisher.

Published in J. Environ. Qual. 38:1803-1811 (2009).

doi:10.2134/jeq2008.0361

Received 12 Aug. 2008.

*Corresponding author (scomfort@unl.edu).

(1) ASA, CSSA, SSSA

677 S. Segoe Rd., Madison, WI 53711 USA
THE Environmental Protection Agency (EPA) estimated 1 that in 1999, the United States had approximately 20,000 agrichemical firms that distributed roughly 5 billion pounds of fertilizers and pesticides (USEPA, 1999, p. 8-20). Given that most U.S. agriculture is heavily dependent on the use of pesticides and fertilizers, it is likely that chemical spills and inadvertent discharges of agrichemicals will continue to occur around farmsteads and dealerships. Although numerous improvements have been made in construction of pesticide containment facilities, surveys of pesticide distributors indicate prevalent soil contamination (Minnesota Department of Agriculture, 1997). These accidental releases have the potential to create soil concentrations that are several orders of magnitude greater than soils receiving agronomic rates (i.e., labeled rates). High concentrations are problematic because pesticides that may readily biodegrade at labeled-rate concentrations may persist at high concentrations due to the inhibition of microbial activity and low degradation rates (Grant and Williams, 1982; Gan and Koskinen, 1998). Furthermore, if soil adsorption sites become saturated (i.e., nonlinear adsorption), high concentrations can result in lower soil adsorption coefficients and increased transport (i.e, chemical nonequilibrium transport).

Although individual State regulations may vary, pesticide spills are usually handled in one of the two ways. The contaminated soil is excavated and shipped to a certified landfill or the contaminated soil is reapplied to farmland at labeled rates. When contaminated soils also contain banned or toxic chemicals, a third option of incineration may also be considered. None of these approaches treat the contaminated soil on-site and all are costly and often labor intensive.

Identifying and remediating point-sources of pesticide contamination is a major undertaking. The Nebraska Department of Agriculture has begun to identify several pesticide-contaminated sites across Nebraska and is seeking aid in developing remedial protocols and treatments. In 2005, soil samples obtained from an abandoned

M. Waria, S.D. Comfort, and H. Boparai, School of Natural Resources, Univ. of Nebraska, Lincoln, NE 68583-0915; S. Onanong, D.D. Snow, and D.A. Cassada, Water Sciences Lab., Univ. of Nebraska, Lincoln, NE 68583-0844; T. Satapanajaru, Dep. of Environmental Science, Kasetsart Univ., Bangkok, Thailand 10900; C. Harris, Dep. of Chemistry, Albion College, Albion, MI 49224.

Abbreviations: $\mathrm{Fe}^{0}$, zerovalent iron; HPLC, high performance liquid chromatography; LC/MS, liquid chromatography/mass spectrometry; MDA, Minnesota Department of Agriculture. 
fertilizer dealership in western NE revealed high concentrations of the herbicides atrazine $\left(-500 \mathrm{mg} \mathrm{kg}^{-1}\right)$ and cyanazine $\left(-900 \mathrm{mg} \mathrm{kg}^{-1}\right)$. The research presented within provides a series of procedures and experiments undertaken with the goal of remediating the pesticide-contaminated site. Specifically, we grid sampled the contaminated site to spatially delineate the extent of contamination; conducted laboratory treatability studies to determine optimum treatments for pesticide destruction using chemical, biological, and combined approaches; and finally, performed a field-scale cleanup of the contaminated site.

\section{Materials and Methods}

\section{Pesticide Spill Site}

The pesticide spill site was a former agrichemical dealership in western Nebraska. This site had been abandoned for several years with most of the original buildings and storage containers removed. Historical maps of the agrichemical dealership provided guidance on where past chemical handling activities occurred and likely locations for soil contamination. The abandoned site was grid sampled by spacing coordinates $4.57 \mathrm{~m}$ apart and covering a 20 by $40 \mathrm{~m}$ area. Soil samples were taken at coordinate intersections except where physical structures (e.g., buildings, pavement, or foundations) prevented sampling. Two soil samples were taken per coordinate (one from 0-30 cm and one from 30-60 cm). Each soil sample was placed in a Whirl-Pak plastic bag (Nasco, Modesto, CA) and stored in coolers until transported back to the laboratory where they were held at $4^{\circ} \mathrm{C}$ until analysis (24-72 h).

Soil samples were passed through a $2-\mathrm{mm}$ screen and a subset sent to Midwest Laboratories (Omaha, NE) for pesticide screening. In brief, the pesticide screening analysis followed the Minnesota Department of Agriculture's standard operating procedures (SOP) 26c (Extraction of Neutral Extractable Pesticides from Soil) where soil extracts were concentrated to 5 $\mathrm{mL}$ in $60 / 40(\mathrm{v} / \mathrm{v})$ isooctane/toluene and quantitative analysis of pesticides done by gas chromatography following SOP $27 \mathrm{~d}$ (Chromatography and Quality Control for Neutral Extractable Pesticides in Water; Minnesota Department of Agriculture, 1997), referred to USEPA Method 507. Results from the pesticide screening showed that the two major pesticides present in the contaminated soil were atrazine and cyanazine. All soil samples obtained by grid sampling were subsequently analyzed for atrazine and cyanazine by high-performance liquid chromatography (HPLC) (methodologies given below).

Atrazine and cyanazine concentrations along with grid coordinates were entered into graphical software (SigmaPlot, Systat Software, San Jose, CA) to generate contour plots of soil contamination. A front-end loader was then used to remove and place the contaminated soil into two windrows (North and South) on top of a $15 \mathrm{~cm}$ bed of sand. The area from which the soil was removed was resampled to verify the removal of contamination. Additional soil removal was required in some areas and resulted in the total soil volume of $275 \mathrm{~m}^{3}\left(360 \mathrm{yd}^{3}\right)$. Both windrows were triangular in shape and approximately 3 $\mathrm{m}$ wide by $1.5 \mathrm{~m}$ high. Lengths of the windrows were $67 \mathrm{~m}$ for the North and $50 \mathrm{~m}$ for the South.
Soil in both windrows (North and South) was mixed three times within $24 \mathrm{~h}$ by using a tractor-pulled high speed mixing and fractionation implement (Frontier Industrial Corp., Salem, OR), sold under the trade name Microenfractionator (H\&H Ecosystems, North Bonneville, WA). This implement is similar in appearance to a conventional composter but differs in that its components have been augmented and redesigned to handle windrows containing $100 \%$ soil. Soil mixing is facilitated by a John Deere (Moline, IL) 6068T 170-horsepower diesel engine that propels a large $32-\mathrm{cm}$ (diam.) stainless steel rotating drum with 50 fan-knife blades (30.8-cm length). This implement also allows simultaneous injection of liquids into the mixing tunnel via pressurized lines connected to a mobile holding tank, which is pulled behind the Microenfractionator. Once the soil was mixed, a sample of the contaminated soil was taken back to the laboratory and used in treatability studies.

\section{Pesticide Solution-Iron Suspension Experiments}

Aqueous solutions of atrazine and cyanazine were prepared in deionized water using commercial standards with the following purities: atrazine, 98\%; cyanazine, 99.5\% (Chem Service, West Chester, PA). Batch experiments were conducted in $125-\mathrm{mL} \mathrm{Er-}$ lenmeyer flasks filled with $100 \mathrm{~mL}$ of either atrazine $\left(20 \mathrm{mg} \mathrm{L}^{-1}\right)$ and cyanazine $\left(20 \mathrm{mg} \mathrm{L}^{-1}\right)$ solutions. All flasks were covered with Parafilm M (Pechiney Plastic Packaging, Chicago, IL) and agitated on a reciprocating shaker at ambient temperature $\left(23^{\circ} \mathrm{C}\right)$.

We first quantified the ability of three commercial zerovalent iron sources to degrade atrazine and cyanazine in aqueous solutions. The three iron sources were obtained from Peerless Metal Powders (Detroit, MI) and designated as (i) unannealed iron; (ii) iron aggregate 60D; and (iii) SP4. Each iron source was evaluated $(n=3)$ by adding $2.5 \mathrm{~g}$ to $100 \mathrm{~mL}$ of pesticide solutions (atrazine and cyanazine, $20 \mathrm{mg} \mathrm{L}^{-1}$ ). At 0, 6, 12, 24, $48,96,120$, and $144 \mathrm{~h}, 1.5-\mathrm{mL}$ aliquots were removed and transferred to $1.7-\mathrm{mL}$ polypropylene microcentrifuge tubes, centrifuged at $13,000 \times g$ for $10 \mathrm{~min}$, and analyzed by HPLC for atrazine and cyanazine.

Additional experiments further evaluated Iron Aggregate $60 \mathrm{D}(2.5 \mathrm{~g})$ to degrade atrazine and cyanazine $(100 \mathrm{~mL}$, $20 \mathrm{mg} \mathrm{L}^{-1}$ ) with and without $1 \mathrm{~g}$ of commercial-grade $\mathrm{FeSO}_{4} \cdot 7 \mathrm{H}_{2} \mathrm{O}$. Each treatment (including control) was replicated three times. At 0, 2, 4, 6, 10, 24, 48, 72, 120, and $144 \mathrm{~h}$, $1.5-\mathrm{mL}$ aliquots were removed and transferred to $1.7-\mathrm{mL}$ polypropylene microcentrifuge tubes, centrifuged at $13,000 \times g$ for $10 \mathrm{~min}$, and analyzed by HPLC for atrazine and cyanazine.

\section{Liquid Chromatography/Mass Spectrometry of Degradation Products}

Selected aliquots from the atrazine solution experiment $\left(\mathrm{Fe}^{0}\right.$ $+\mathrm{FeSO}_{4}$ ) were analyzed by LC/MS to identify possible degradation products. Transformation products were confirmed by LC/ MS using standards under the same conditions but we did not quantify changes in concentrations of the degradation products. Atrazine products were characterized on a Finnigan LCQ ion trap mass spectrometer (Thermo Sci., Waltham, MA) with chro- 
matographic separation on a Waters 2695 HPLC (Waters Corp., Milford, MA) and a Phenomenex Luna $5 \mu$ C8(2) $2.1 \times 200 \mathrm{~mm}$ column held at $31^{\circ} \mathrm{C}$. Mobile phase was a $90: 10$ ratio of $0.1 \%$ $(\mathrm{v} / \mathrm{v})$ ammonium formate in water and $10 \%(\mathrm{v} / \mathrm{v})$ methanol for the first $2 \mathrm{~min}$, followed by a $16 \mathrm{~min}$ gradient to a 20:80 mobile phase ratio, held for $2 \mathrm{~min}$, then returned to a 90:10 ratio for the remainder of the run $(8 \mathrm{~min})$. The flow rate was $0.2 \mathrm{~mL} \mathrm{~min}{ }^{-1}$ and sample injection volume was $25 \mu \mathrm{L}$. Data was collected in full scan positive ion mode from a mass range of 80 to $400 \mathrm{amu}$. Electrospray ionization source tuning was optimized using hydroxyatrazine. Ion source parameters were: sheath gas flow, 75 (arbitrary units); auxiliary gas flow, 15 (arbitrary units); spray voltage, $4.5 \mathrm{kV}$; heated capillary temperature, $150^{\circ} \mathrm{C}$; capillary voltage, $25 \mathrm{~V}$ and tube lens voltage, $7.0 \mathrm{~V}$.

\section{Soil Microcosm Experiments}

Solution experiments confirmed that atrazine and cyanazine were degraded by $\mathrm{Fe}^{0}+\mathrm{FeSO}_{4}$. Soil incubation studies involved using the same chemical treatment as the solution experiment $\left(\mathrm{Fe}^{0}+\mathrm{FeSO}_{4}\right)$, a biological treatment, and a combined approach. Biological treatment involved adding emulsified soybean oil (EOS, Raleigh, NC) as a C source to promote cometabolism of the pesticide.

Soil incubations were performed with $20 \mathrm{~g}$ soil (air-dry soil) in $40-\mathrm{mL}$ Teflon tubes. Soils used in all treatability studies came from the contaminated site. Given that for field-scale treatment, this soil would be excavated and mixed with lower subsoil, we also mixed the surface samples with subsoil to get lower and more uniform concentrations $\left(-20\right.$ to $30 \mathrm{mg} \mathrm{kg}^{-1}$ for both atrazine and cyanazine).

For the biological treatment, we used EOS 598B42, which also contained a vitamin $\mathrm{B}_{12}$ supplement. To determine what concentration of soybean oil to add to the soil, screening experiments were performed that varied soybean oil concentration. Results led us to dilute the EOS product 100 -fold with water $(1 \%, \mathrm{v} / \mathrm{v})$ and shake overnight. We then added $6 \mathrm{~mL}$ of the oil-water suspension to $20 \mathrm{~g}$ of soil and incubated at $30^{\circ} \mathrm{C}$. Soil water content was maintained between 0.30 to $0.35 \mathrm{~kg} \mathrm{~kg}^{-1}$ during the $21 \mathrm{~d}$ experiment. Temporal sampling of atrazine concentration occurred by sacrificial sampling of the microcosms by extracting with $\mathrm{CH}_{3} \mathrm{CN}$.

To evaluate the combined chemical and biological treatment, treatments included (i) $\mathrm{Fe}^{0}$ (ii) $\mathrm{Fe}^{0}+\mathrm{FeSO}_{4}$ (iii) $\mathrm{Fe}^{0}+\mathrm{FeSO}_{4}+$ EOS Oil (598B42). When included as a treatment component, the amount of amendments added to the $20 \mathrm{~g}$ of soil included: (i) $0.5 \mathrm{~g} \mathrm{Fe}^{0}$; (ii) $0.2 \mathrm{~g} \mathrm{FeSO}_{4} \cdot 7 \mathrm{H}_{2} \mathrm{O}$; and (iii) $6 \mathrm{~mL}$ EOS $598 \mathrm{~B} 42$ oil $(1 \%, v / v)$. Microcosms were incubated at $30^{\circ} \mathrm{C}$ and soil water content maintained between 0.30 and $0.35 \mathrm{~kg} \mathrm{~kg}^{-1}$ for $60 \mathrm{~d}$. Temporal samplings occurred by extracting the microcosms with $20 \mathrm{~mL}$ of $\mathrm{CH}_{3} \mathrm{CN}$ for analysis of extractable atrazine and cyanazine by HPLC (procedure described in soil analysis below).

\section{Field Experiment}

Before and after treatment, five to six soil samples were taken from the east side of the windrows every $3 \mathrm{~m}$, mixed in a bucket and transferred to a Whirl-Pak bag. Samples were placed in an insulated cooler, transported back to laboratory and stored at $4^{\circ} \mathrm{C}$ until analysis. Each sample was then analyzed for atrazine and cyanazine and average pesticide concentrations per windrow were calculated.

After the first sampling ( $\mathrm{T}=0 \mathrm{~d})$, the combined chemicalbiological treatment $\left(\mathrm{Fe}^{0}+\mathrm{FeSO}_{4} \cdot 7 \mathrm{H}_{2} \mathrm{O}+\mathrm{EOS} 598 \mathrm{~B} 42\right)$ was applied to both the North and South windrows. The logistics of treating the contaminated soil at this particular site did not allow us to leave one windrow as an untreated control. Thus, the role of natural attenuation vs. abiotic degradation (from the chemical treatment) cannot be differentiated from the field data. In a previous study, where a control was used (Comfort et al., 2001), significant differences between the abiotic treatment and the control were observed.

Iron $\left(\mathrm{Fe}^{0}\right)$ and $\mathrm{FeSO}_{4}$ were added as percentage of the ovendry soil mass, which was estimated by multiplying the volume of each windrow times a soil bulk density of $1.4 \mathrm{~g} \mathrm{~cm}^{-3}$. The iron was added at $2.5 \%(\mathrm{w} / \mathrm{w})$ and $\mathrm{FeSO}_{4} \cdot 7 \mathrm{H}_{2} \mathrm{O}$ at $1 \%(\mathrm{w} / \mathrm{w})$. The emulsified oil was applied by mixing the concentrated product with water and spraying the liquid into the mixing chamber during soil mixing. Expressing the chemical amendments in units of mass of chemical added per cubic yard $\left(1\right.$ yard $\left.=0.765 \mathrm{~m}^{3}\right)$ of soil (1070 kg or $2360 \mathrm{lb}$, assuming $1.4 \mathrm{~g} \mathrm{~cm}^{-3}$ bulk density), our treatment rates were equivalent to $24.99 \mathrm{~kg}(55.55 \mathrm{lb})$ of $\mathrm{Fe}^{0}$, $9.99 \mathrm{~kg}(22.22 \mathrm{lb})$ of $\mathrm{FeSO}_{4} \cdot 7 \mathrm{H}_{2} \mathrm{O}$ and $2.87 \mathrm{~L}(0.76 \mathrm{gal})$ of EOS 598B 42 per $0.765 \mathrm{~m}^{3}\left(1.0 \mathrm{yd}^{3}\right)$ of contaminated soil.

The $\mathrm{Fe}^{0}$ and and $\mathrm{FeSO}_{4} \cdot 7 \mathrm{H}_{2} \mathrm{O}$ (in $22.6 \mathrm{~kg}$ bags) were placed on the top of the windrows and directly mixed into the contaminated soil by the soil mixer a minimum of three times. Water and EOS 598 B42 oil were mixed together in $3790 \mathrm{~L}$ (1000 gallon) tanks and added during the mixing process until the soil gravimetric water content reached between 0.35 and $0.40 \mathrm{~kg} \mathrm{~kg}^{-1}$, which was determined on site by weight loss following repeated cycles of heating subsamples of soil from the windrows in a microwave oven.

Once desired water content was achieved, the windrows were tightly covered with clear plastic sheeting that was held in place with sand placed along the periphery of the windrows. Temporal changes in volumetric soil water content were measured by ML2 type probes with a handheld $\mathrm{HH} 2$ reader (Delta-T Devices, Ltd, Cambridge, UK). Probes were inserted into the windrows at approximately $60 \mathrm{~cm}$ depth and spaced 12 to $18 \mathrm{~m}$ apart. Four probes were placed in both the North and South windrows. Soil temperature was measured with a bimetal thermometer that had a stem length of $60.96 \mathrm{~cm}$ (Cole Parmer, Vernon Hills, IL). The tip of the thermometer was placed at three depths: 15,30 , and $45 \mathrm{~cm}$ and temperature readings taken at six locations on the South windrow and eight locations on the North windrow approximately every 3 to $9 \mathrm{~m}$.

Windrows were sampled for temporal changes in pesticide concentrations at 7, 14, 21, 30, 60, 250, 270, $315 \mathrm{~d}$. Soil windrows were sampled approximately every $3 \mathrm{~m}$ by cutting a slit into the plastic covering midway up the side of the windrow, removing three to five soil cores with a hand-held auger, combining the samples into a bucket and placing the composite sample into a plastic bag. Plastic sheeting was resealed after 
sampling to avoid soil water loss. After the $315 \mathrm{~d}$ sampling, all plastic covering was removed from the windrows and soil remixed with the soil mixer and the soil was again sampled for pesticide concentration at $342 \mathrm{~d}$.

\section{Soil Analysis}

Soil samples obtained from the windrows were inventoried and stored at $4^{\circ} \mathrm{C}$ until analysis. For each sample, soil water content, $\mathrm{pH}$, atrazine, and cyanazine concentrations were determined. Soil water content was determined on $\sim 10$-g subsamples by quantifying weight loss after drying in a microwave oven. Soil pH was determined on 20-g soil samples (oven dry basis) using a 1:2 soil to water ratio.

Atrazine and cyanazine concentrations were determined in soil microcosm experiments and from the field experiment by extracting $20 \mathrm{~g}$ of soil in a $40-\mathrm{mL}$ Teflon centrifuge tube with $20 \mathrm{~mL} \mathrm{CH}_{3} \mathrm{CN}$ and shaking overnight $(\geq 8 \mathrm{~h}$ ) on a reciprocating shaker at ambient temperature $\left(20-25^{\circ} \mathrm{C}\right)$. The tubes were then centrifuged at $5000 \times g$ for $10 \mathrm{~min}$. After centrifuging, $1 \mathrm{~mL}$ of the supernatant was stored in a glass $\mathrm{HPLC}$ vial at $4^{\circ} \mathrm{C}$ until analysis. Changes in acetonitrile-extractable concentrations were used to gauge the effectiveness of the remedial treatments.

Atrazine, cyanazine, and products were measured by HPLC by injecting $20 \mu \mathrm{L}$ of aqueous or $\mathrm{CH}_{3} \mathrm{CN}$ extract into a Hypersil gold column $(250 \times 4.6 \mathrm{~mm})$ (Thermo Electron Corporation, Waltham, MA) connected to Shimadzu (Kyoto, Japan) photodiode array detector with quantification at $220 \mathrm{~nm}$. Peak areas were integrated and compared to certified standards. The mobile phase was 50:50 acetonitrile and water at a flow rate of

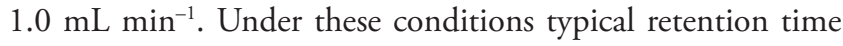
were $6 \mathrm{~min}$ for atrazine and $4 \mathrm{~min}$ for cyanazine.

Standard soil nutrient analysis and metal analyses (Table 1) were conducted by Midwest Analytical Laboratories (Omaha, $\mathrm{NE})$ on initial $(\mathrm{t}=0 \mathrm{~d})$ and final $(\mathrm{t}=342 \mathrm{~d})$ samples.

Table 1. Soil chemical-physical properties before and after chemicalbiological treatment.

\begin{tabular}{|c|c|c|c|}
\hline Soil property & Unit & $\begin{array}{l}\text { Initial } \\
(T=0 \mathrm{~d})\end{array}$ & $\begin{array}{c}\text { Final } \\
(\mathrm{T}=342 \mathrm{~d})\end{array}$ \\
\hline Phosphorus (weak Bray) & $\mathrm{mg} \mathrm{kg}^{-1}$ & $810(95.9) \dagger$ & $20(2.0)$ \\
\hline Nitrate-N & $\mathrm{mg} \mathrm{kg}^{-1}$ & $1836(93.6)$ & $496(156)$ \\
\hline Ammonium N & $\mathrm{mg} \mathrm{kg}^{-1}$ & $772(113)$ & $361(54)$ \\
\hline Organic matter & $\%$ & $5(0.3)$ & $4(0.4)$ \\
\hline Cation exchange capacity & $\mathrm{cmol}_{\mathrm{c}} \mathrm{kg}^{-1}$ & $30(1.8)$ & $20(4.8)$ \\
\hline Chloride & $\mathrm{mg} \mathrm{kg}^{-1}$ & $62(2.0)$ & $47(12)$ \\
\hline Sulfur & $\mathrm{mg} \mathrm{kg}^{-1}$ & $627(40.1)$ & $999(0)$ \\
\hline Iron (DTPA) & $\mathrm{mg} \mathrm{kg}^{-1}$ & $38(4.6)$ & $143(11)$ \\
\hline Zinc (DTPA) & $\mathrm{mg} \mathrm{kg}^{-1}$ & $66(7.3)$ & $33(6.5)$ \\
\hline Manganese (DTPA) & $\mathrm{mg} \mathrm{kg}^{-1}$ & $32(2.9)$ & $65(2.0)$ \\
\hline Copper (DTPA) & $\mathrm{mg} \mathrm{kg}^{-1}$ & $6(0.8)$ & $15(0.9)$ \\
\hline Boron & $\mathrm{mg} \mathrm{kg}^{-1}$ & $2(0.2)$ & $2(0.2)$ \\
\hline Aluminum & $\mathrm{mg} \mathrm{kg}^{-1}$ & $4(2.0)$ & $1(0)$ \\
\hline $\mathrm{pH}$ & & $5(0.1)$ & $6(0.4)$ \\
\hline Sand & $\%$ & $75(3.1)$ & $78(2.0)$ \\
\hline Silt & $\%$ & $15(4.2)$ & $12(8.7)$ \\
\hline Clay & $\%$ & $9(1.2)$ & $10(6.9)$ \\
\hline
\end{tabular}

† Parenthetic values represent sample standard deviation $(n=3)$.

\section{Results and Discussion}

\section{Pesticide Solution- Iron Suspension Experiments}

A comparison of atrazine and cyanazine destruction by the three iron sources showed that Iron Aggregate 60D was superior in transforming the pesticides. Using only $2.5 \mathrm{~g}$ of $\mathrm{Fe}^{0}$ per 100 $\mathrm{mL}$, Iron Aggregate $60 \mathrm{D}$ resulted in nearly $50 \%$ removal of atrazine whereas reaction with the Unannealed and SP4 iron only removed around 20\% (Fig. 1A). Similarily, 40\% of cyanazine was converted with Iron Aggregate 60D as compared to $15 \%$ with Unannealed iron and 15\% with SP4 iron (Fig. 1B). When higher iron loading rates were used (i.e., $5 \mathrm{~g}$ per $100 \mathrm{~mL}$ ) about $80 \%$ of the atrazine was removed (data not shown). Subsequent extraction of the iron with $\mathrm{CH}_{3} \mathrm{CN}$ showed no residual bound atrazine. The lack of extractable parent compound from the iron combined with the production of degradation products (see LC/ MS results) indicates that loss of atrazine and cyanazine from solution were likely due to transformation and not adsorption. However, adsorption of atrazine or cyanazine transformation products and co-precipitation are also possible removal mechanisms. Co-precipitation has been documented to occur with heavy metals and natural and dissolved organic matter (Crawford et al., 1993; Gu et al., 1994; Satoh et al., 2006). Moreover, Singh et al. (1988b) using ${ }^{14} \mathrm{C}$-atrazine and a different iron source than used in these experiments showed that nonextractable residues of atrazine could form on exposure to iron. From a remediation standpoint, forming unextractable residue to the iron surface could also be viewed as an acceptable endpoint.

Previous research has demonstrated iron source (i.e., composition) and surface area can greatly impact destruction efficiencies. Chromium (VI) reduction (Powell et al., 1995; Blowes et al., 1997; Alowitz and Scherer, 2002) as well as RDX and TNT destruction (Singh et al., 1998a; Park et al., 2004) were found to vary significantly depending on the characteristics of the iron source. The herbicide metolachlor was also found to more efficiently transform by annealed rather than unannealed iron, which was in part explained by differences in surface area (Satapanajaru et al., 2003a). The surface area of the iron sources used in this study were measured by gas adsorption with the Brunauer, Emmet, and Teller theory and determined to be $3.85 \mathrm{~m}^{2} \mathrm{~kg}^{-1}$ for Iron Aggregate 60D, $2.89 \mathrm{~m}^{2} \mathrm{~kg}^{-1}$ for the Unannealed iron, and $0.15 \mathrm{~m}^{2} \mathrm{~kg}^{-1}$ for the SP4 iron (Micromeritics, Norcross, GA). Although Iron Aggregate 60D had the highest surface area and was the most efficient in transforming the pesticides, similar destruction efficiencies between Unannealed iron and SP4 (Fig. 1) (which differed in surface areas), indicate iron composition was also a factor.

As previously demonstrated with other pesticides such as metolachlor (Satapanajaru et al., 2003a) and dicamba (Gibb et al., 2004), the addition of a salt to the $\mathrm{Fe}^{0}$-pesticide matrix significantly increased atrazine and cyanazine destruction. While $\mathrm{Fe}^{0}$ alone transformed approximately $40 \%$ of the atrazine, adding $\mathrm{FeSO}_{4}$ increased pesticide loss to more than $90 \%$ within $6 \mathrm{~d}$ (Fig. 2). A comparison of pesticides (Fig. 2A vs. 2B) showed that atrazine was slightly more reactive than cyanazine. Our results are consistent with previous reports of salt amendments mak- 


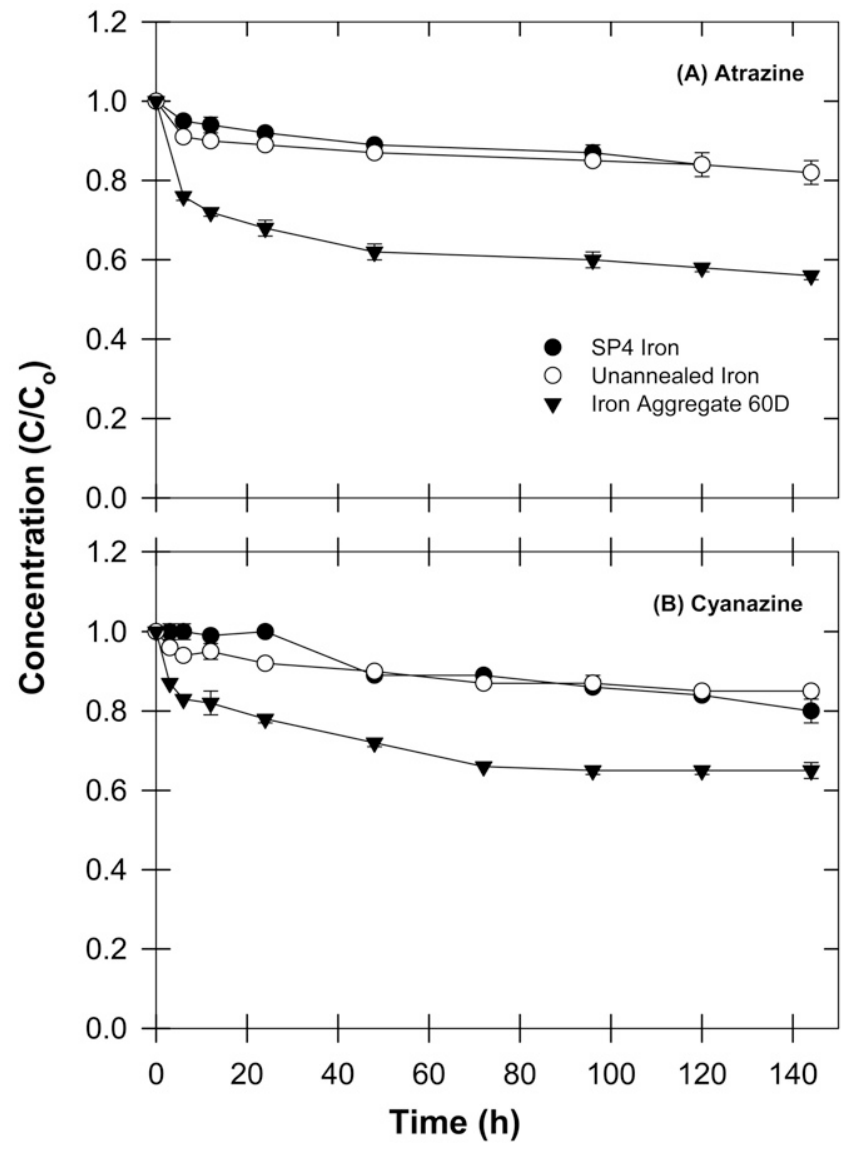

Fig. 1. Temporal changes in concentration of $(A)$ atrazine and (B) cyanazine following treatment with three iron metals. Initial atrazine and cyanazine concentrations were $20 \mathrm{mg} \mathrm{L}^{-1}$ and treated with $2.5 \% \mathrm{Fe}^{0}$ $(w / v)$. Bars indicate sample standard deviations $(n=3)$.

ing iron metal more efficient in degrading pesticides (Comfort et al., 2001; Satapanajaru et al., 2003a). Adding ferrous sulfate reduced solution $\mathrm{pH}$ and provided a source of $\mathrm{Fe}(\mathrm{II})$ and sulfate, both of which facilitated the formation of green rust, which also acts as a strong reductant (Satapanajaru et al., 2003b).

\section{Liquid Chromatography/Mass Spectrometry Analysis}

The LC/MS analysis of atrazine solutions treated with $\mathrm{Fe}^{0}$ $+\mathrm{FeSO}_{4}$ indicated that deethylatrazine (DEA), deisopropylatrazine (DIA), hydroxyatrazine (HA), and ammelines were formed (Fig. 3). Singh et al. (1998b) similarly observed the formation of DEA, DIA, HA, and didealkylatrazine following the treatment of atrazine with zerovalent iron. Thus both dealkylation and hydrolysis occurred by this abiotic treatment.

Surface-catalyzed hydrolysis is well known and several Fe and $\mathrm{Al}$ oxides have been shown to catalyze organic hydrolysis reactions, at least those known to be $\mathrm{OH}^{-}$catalyzed (Hoffman, 1990). Previous research has shown that several iron oxyhydroxides could potentially form during treatment of organic contaminants with $\mathrm{Fe}^{0}$ (i.e., $\alpha-\mathrm{FeOOH}, \beta-\mathrm{FeOOH}, \alpha-\mathrm{Fe}_{2} \mathrm{O}_{3}$, and $\gamma-\mathrm{Fe}_{2} \mathrm{O}_{3}$; Satapanajaru, 2002). Although the $\mathrm{OH}^{-}$ion activity is greater at the positively charged oxide surface than in solution, coordination between structural Fe (III) (Lewis acid) and the organic functional groups is a probable cause of decomposition (McBride, 1994).

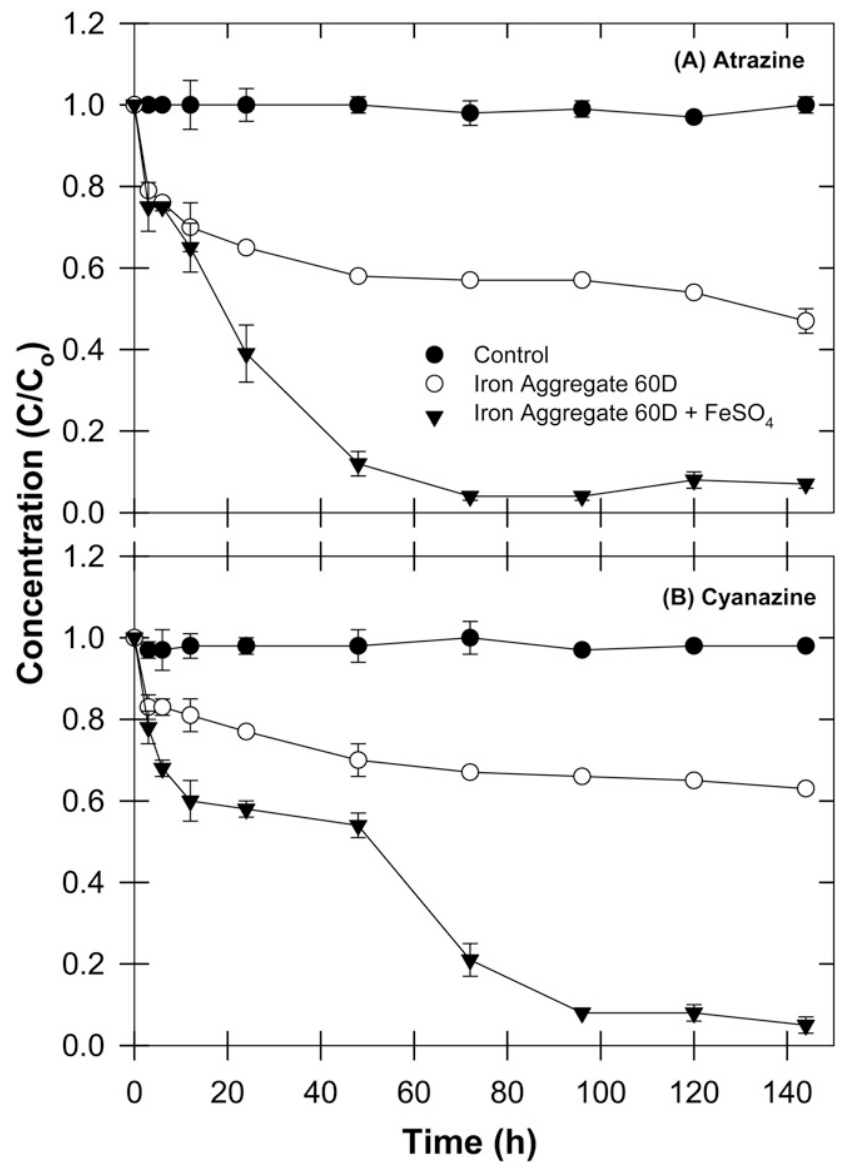

Fig. 2. Temporal changes in concentrations of $(A)$ atrazine and (B) cyanazine following treatment with Iron Aggregate $60 \mathrm{D}$, with and without $\mathrm{FeSO}_{4}$. Initial pesticide concentrations were $20 \mathrm{mg} \mathrm{L}^{-1}$ and treated with $2.5 \% \mathrm{Fe}^{0}(\mathrm{w} / \mathrm{v})$ and $1 \% \mathrm{FeSO}_{4}$. Bars indicate sample standard deviations $(n=3)$.

Therefore, we similarly show how Fe (III) in an iron oxide coatings could facilitate atrazine hydrolysis (Fig. 4A).

Shin and Cheney $(2004,2005)$ also showed how dealkylation occurs when atrazine weakly binds to Mn oxide surfaces through the ring $\mathrm{N}$ or amino groups. The first step in the dealkylation mechanism is the partial oxidation of atrazine by exchange of electrons via an $N=\mathrm{Mn}$ (IV) double bond formed through $\pi$ bonding. The rearrangement of $-\mathrm{HN}=\mathrm{Mn}-$ $\mathrm{OH}$ fraction to $-\mathrm{H}_{2} \mathrm{~N}-\mathrm{Mn}=\mathrm{O}$ occurs and dissociation of the bound amine completes the dealkylation reaction. Given that we observed similar atrazine degradation products found by Shin and Cheney $(2004,2005)$, a similar dealkylation of atrazine by iron oxide is presented (Fig. 4B).

\section{Soil Microcosm Experiments}

Although batch solution experiments indicated that addition of $\mathrm{FeSO}_{4}$ had a complementary effect on the $\mathrm{Fe}^{0}$-mediated atrazine degradation, the optimum quantities and treatments required to treat the contaminated soil needed to be determined.

Past research has documented increased losses in pesticide concentrations by adding a variety of $\mathrm{C}$ sources. Wagner and Zablotowicz (1997) studied the effects of carbon amendments on cyanazine biodegradation and observed a decrease in cy- 


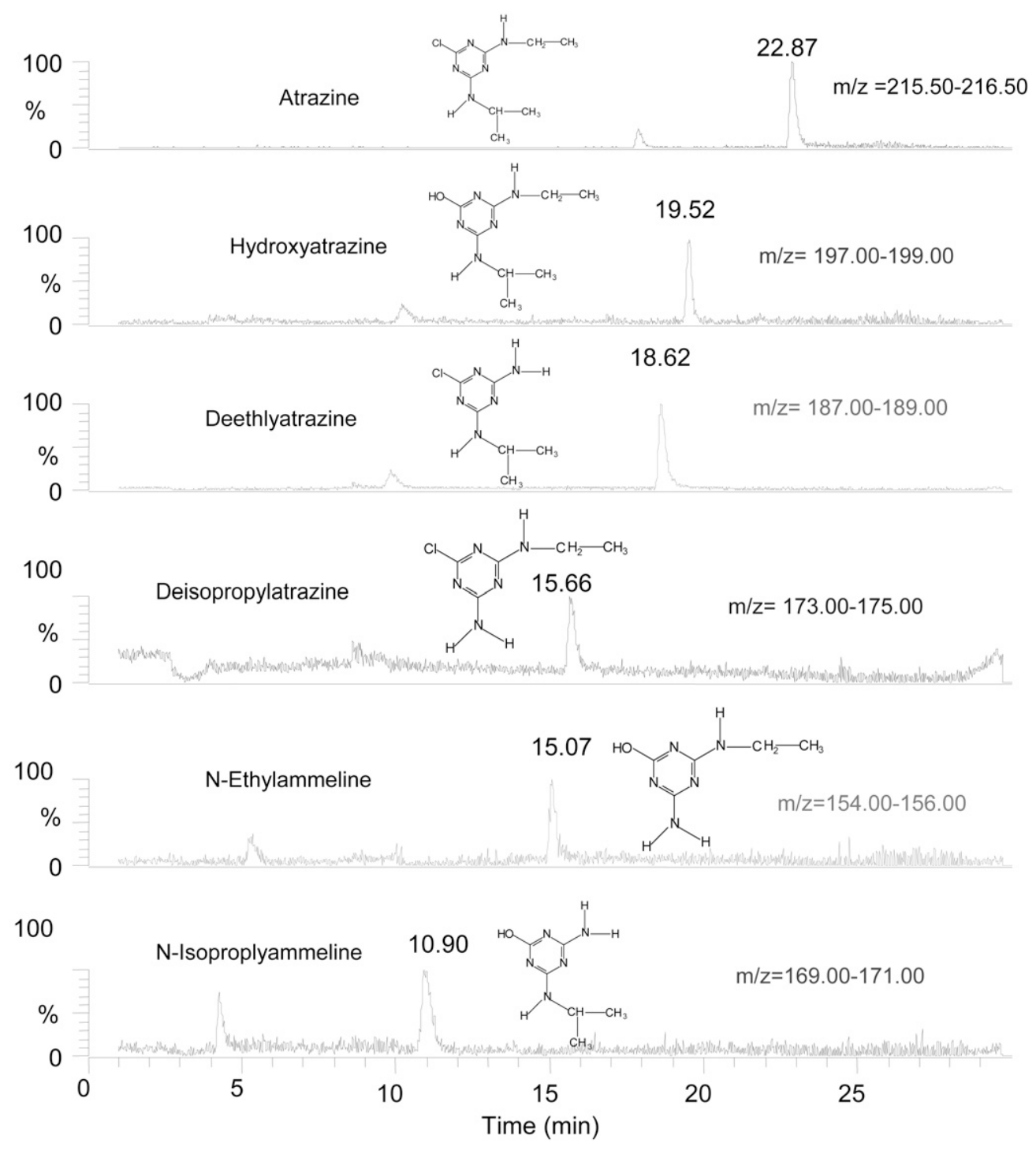

Fig. 3. Ion chromatograms showing atrazine degradation products following treatment of aqueous solution of atrazine with $2.5 \% \mathrm{Fe}{ }^{0}(\mathrm{w} / \mathrm{v}$ ) and $1 \% \mathrm{FeSO}_{4}$

anazine half-life (unamended soils, $\mathrm{t}_{1 / 2}=28.3 \mathrm{~d}$ ) when soils were amended with ryegrass (Lolium multiflorum Lam.) $\left(\mathrm{t}_{1 / 2}=18.2 \mathrm{~d}\right)$, corn meal $\left(\mathrm{t}_{1 / 2}=21 \mathrm{~d}\right)$, or poultry litter $\left(\mathrm{t}_{1 / 2}=21 \mathrm{~d}\right)$. Similarly, biodegradation of acetochlor [2-chloro- $N$-(ethoxymethyl)- $N$ (2-ethyl-6-methylphenyl)acetamide], atrazine, and metolachlor [2-chloro- $N$-(2-ethyl-6-methylphenyl)- $N$-(2-methoxy-1-methylethyl)acetamide] were enhanced by the stimulation of microbial activity with addition of organic fertilizers and amendments (Cai et al., 2007; Moorman et al., 2001). However, when we compared atrazine and cyanazine degradation with and without the commercial product EOS 598B42, we saw no significant differences in overall degradation after $60 \mathrm{~d}$ (Fig. 5). Incubating the air-dried soils with water initially increased extractable pesticide concentrations, which has previously been contributed to the expansion of clays and less sorption (Chiou et al., 1983), but with time, pesticide concentrations in both the water and water + oil treatments decreased at similar rates. Adding the soybean oil, however, did provide one notable observation in that abun- dant fungal growth was observed in the microcosms. The fungus growing on the oil-treated soils was identified as Mucor spp, which is not known to break down complex organic compounds such as pesticides but could impact physiochemical conditions (i.e., temperature and redox).

The benefit of combining chemical and biological treatments together was evaluated by comparing atrazine degradation following treatment with (i) $\mathrm{Fe}^{0}$, (ii) $\mathrm{Fe}^{0}+\mathrm{FeSO}_{4}$, and (iii) $\mathrm{Fe}^{0}, \mathrm{FeSO}_{4}$ and oil (EOS 598B42). The benefit of combining all three amendments was most noticeable within $7 \mathrm{~d}$ where atrazine loss was $73 \%$ compared to $43 \%$ for the $\mathrm{Fe}^{0}+\mathrm{FeSO}_{4}$ and $30 \%$ for the $\mathrm{Fe}^{0}$ alone. After $60 \mathrm{~d}$ of incubation, $78 \%$ of the atrazine was degraded in the chemical-biological treatment compared to $69 \%$ for the $\mathrm{Fe}^{0}$ alone and $73 \%$ for the $\mathrm{Fe}^{0}$ $+\mathrm{FeSO}_{4}$ treatment (Fig. 6). Decreases in extractable pesticide concentrations were also observed in the control treatment $\left(\mathrm{H}_{2} \mathrm{O}\right.$ only, Fig. 6). One of the benefits of the high-speed mechanical mixing is that concentrated zones of pesticides, such 

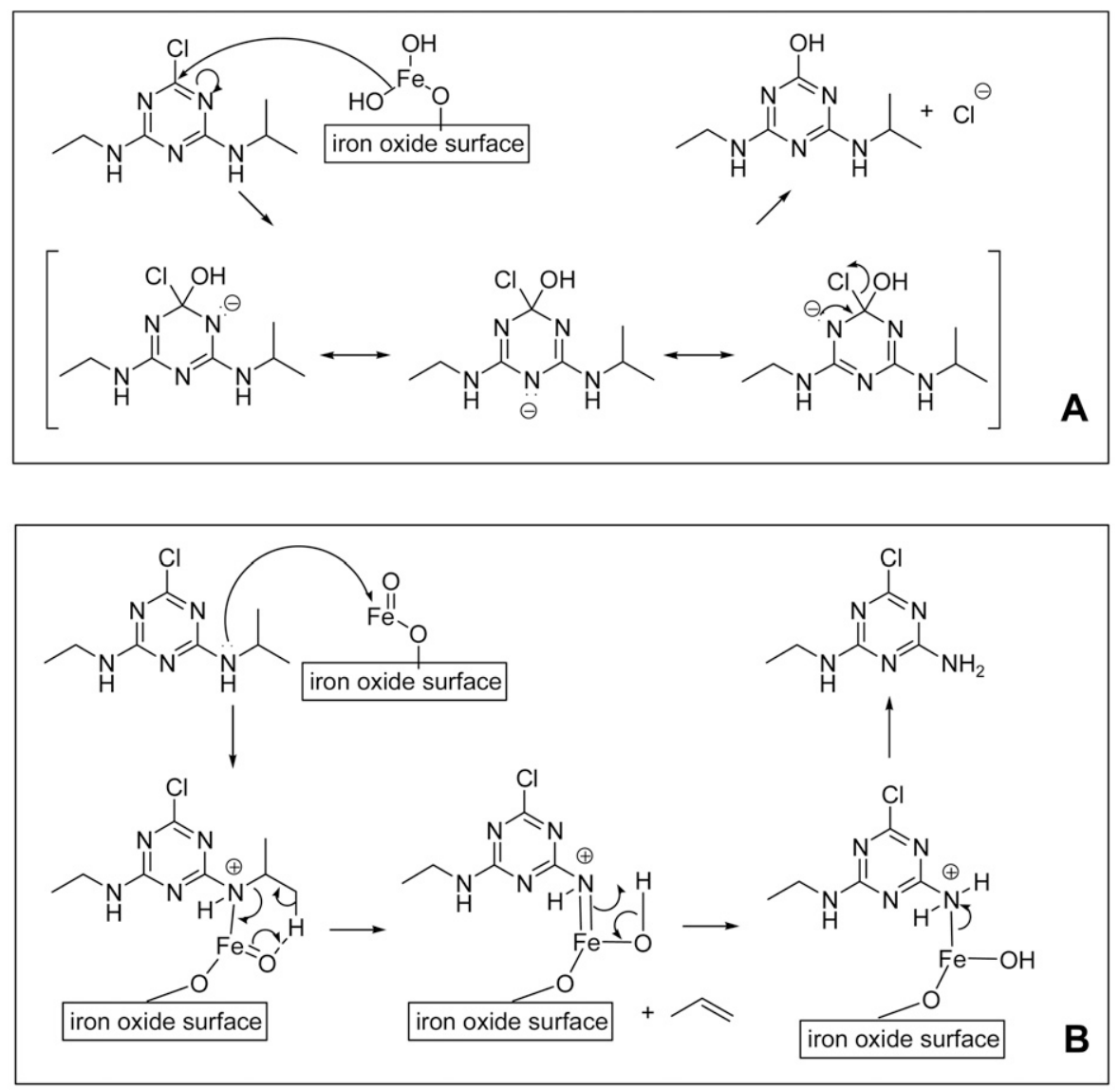

Fig. 4. Proposed mechanism for hydrolysis and dealkylation. (A) Surface catalyzed hydrolysis of atrazine by iron oxide. (B) Dealkylation of atrazine by iron oxide, modeled after Shin and Cheney $(2004,2005)$.

as those observed during grid sampling (i.e., concentrations $>500 \mathrm{mg} \mathrm{kg}^{-1}$ ), were initially lowered to concentrations that did not impede microbial activity.

\section{Field Experiment}

Grid sampling the abandoned fertilizer dealership revealed high concentrations of atrazine and cyanazine. Pesticide concentrations were higher in the surface samples $(0-30 \mathrm{~cm})$ than the deeper samples $(30-60 \mathrm{~cm})$. Maximum concentrations of atrazine were approximately 500 and $900 \mathrm{mg} \mathrm{kg}^{-1}$ for cyanazine while the maximum concentrations below $30 \mathrm{~cm}$ were $160 \mathrm{mg} \mathrm{kg}^{-1}$ for atrazine and $300 \mathrm{mg} \mathrm{kg}^{-1}$ for cyanazine. Following removal of the top $60 \mathrm{~cm}$ and high-speed mixing, soil concentrations dropped at least 10 -fold with mean pesticide concentrations ( $n=15-20)$ averaging 15.87 and $30.25 \mathrm{mg} \mathrm{kg}^{-1}$ for atrazine in the two windrows (Table 2). However, despite considerable mixing of the windrowed soil, pesticide concentrations were still variable as evident by the high standard deviations (Table 2).

Following field treatment of the pesticide-contaminated soil with $\mathrm{Fe}^{0}, \mathrm{FeSO}_{4}$, and $\mathrm{EOS} 598 \mathrm{~B} 42$, average pesticide concentrations (and standard deviations) decreased significantly (Table $2)$. By the second sampling $(t=14 \mathrm{~d})$, atrazine and cyanazine concentrations decreased between 34 and 75\%. After $60 \mathrm{~d}$, average pesticide concentrations had decreased by 72 to $82 \%$ and remained fairly constant until the windrows were mixed again and sampled $(t=342 \mathrm{~d})$. The final sampling showed that the mean pesticide concentrations (atrazine and cyanazine) decreased by $91 \%$ in the North windrow and between 79 and $87 \%$ in the South windrow. Possible reasons for the drop in pesticide concentrations after the final mixing (i.e., $t=315$ vs. 342) may be that routine sampling generally occurred within the top 15 to $30 \mathrm{~cm}$ of the windrow by a handheld auger and that pesticide destruction was more efficient at deeper depths. When we physically dug into the windrows, soils deeper inside the windrows tended to be blacker in color while soils on the outer edge of the windrows were golden or brown in color. This color change is likely a manifestation of the iron oxides formed during corrosion of the added $\mathrm{Fe}^{0}$. Satapanajaru et al. (2003b) previously showed that during $\mathrm{Fe}^{0}$ treatment of metolachlor, goethite and lepidocrocite (yellow-brown color) were products of iron corrosion under aerobic conditions while magnetite (black) forms under anoxic conditions. Although that oxygen content was not measured, oxygen diffusion into the windrows would occur from the outer edges inward and increase as the soil water content decreased. With time, stratification of iron oxides (and colors) would occur by the diffusion of oxygen. Thus, by mixing the windrows, soils in the center and outer edges of the windrow were homogenized before sampling. We similarly observed a decrease in metolachlor concentrations in 


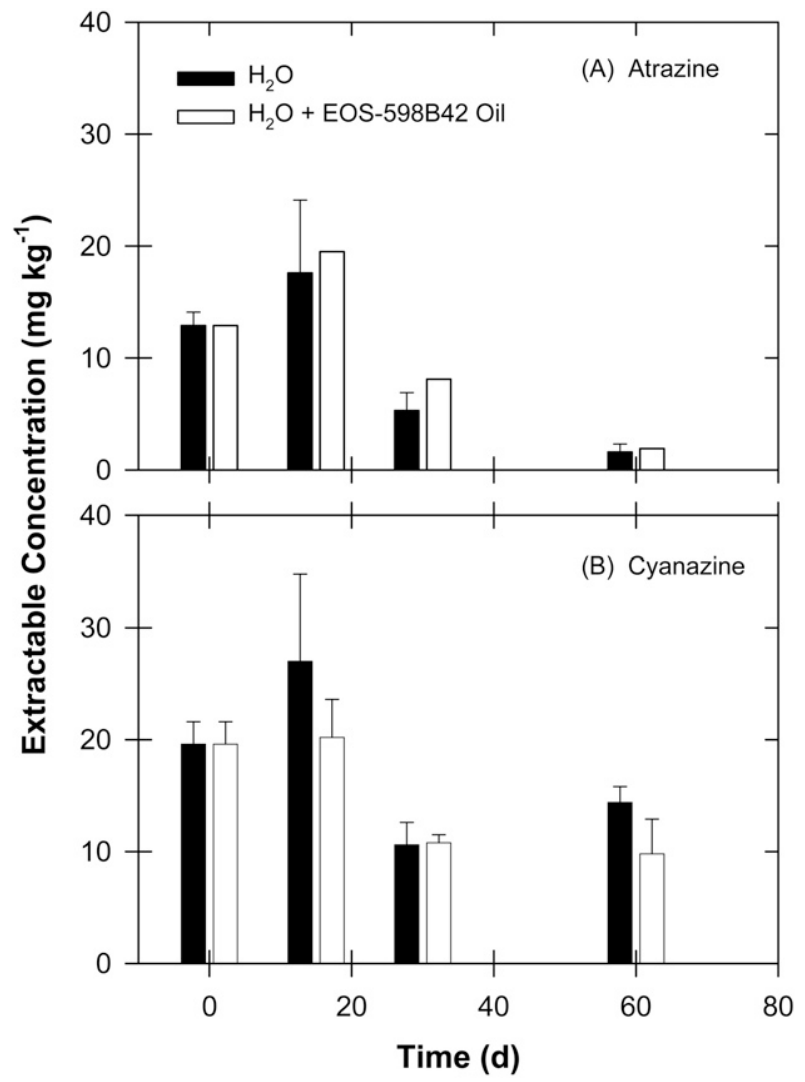

Fig. 5. Temporal changes in $\mathrm{CH}_{3} \mathrm{CN}$-extractable soil concentrations of (A) atrazine and (B) cyanazine following treatment with water and water + Emulsified Oil (EOS 598B42).

a previous field remediation study following the final mixing of the windrows (Comfort et al., 2001). Results from temporal sampling indicate that our chemical-biological treatment of the pesticide-contaminated soil was effective in reducing the pesticide concentrations but given that we could not include an untreated windrow at this particular site, we also acknowledge that natural attenuation may have also contributed to the reduction in pesticide concentrations.

\section{Changes in Soil Physical and Chemical Properties}

Average soil water content during the first $60 \mathrm{~d}$ was 0.40 $\mathrm{cm}^{-3} \mathrm{~cm}^{-3}$ in the North and $0.34 \mathrm{~cm}^{-3} \mathrm{~cm}^{-3}$ in the South wind-

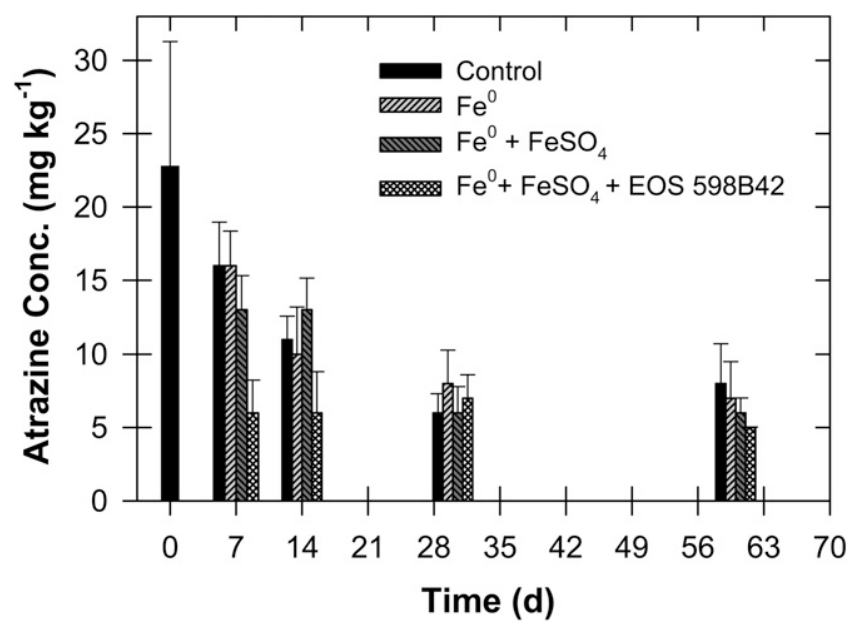

Fig. 6. Temporal changes in $\mathrm{CH}_{3} \mathrm{CN}$-extractable atrazine concentrations following treatment with $\mathrm{Fe}^{0}, \mathrm{FeSO}_{4}$ and Emulsified Oil (EOS 598B42).

row. Even after several months $(t=270 \mathrm{~d})$, the soil water content was $0.20 \mathrm{~cm}^{-3} \mathrm{~cm}^{-3}$ in the North and $0.15 \mathrm{~cm}^{-3} \mathrm{~cm}^{-3}$ in the South. Issa and Wood (2005) observed that atrazine and isoproturon degraded more rapidly in soils with $90 \%$ of field capacity (optimum) than in samples with higher moisture contents. Differences in soil water content between windrows kept the North windrow slightly cooler throughout the experiment. Within $5 \mathrm{~d}$ after treatment, soil temperatures had reached $34.1^{\circ} \mathrm{C}\left(45 \mathrm{~cm}\right.$ depth) in the North windrow and $38.2^{\circ} \mathrm{C}$ in the South windrow. These soil temperatures were consistently 10 to $15^{\circ} \mathrm{C}$ higher than the daytime air temperature. Moreover, sampling temperature with depth $(15,30$, and $45 \mathrm{~cm})$ revealed temperatures were consistently higher at the deeper depths for the first $30 \mathrm{~d}$. This indicates that solar radiation through the clear plastic was not the only source of heat. Rather, the emulsified oil provided a readily utilizable carbon source that not only generated heat through heterotrophic respiration but also likely facilitated reductive transformations by providing an additional oxygen demand, which was confirmed by the observed stratification of soil colors (i.e., iron oxides) with depth. Finally, as observed in the laboratory microcosms experiments, abundant fungal growth was observed under the clear plastic throughout the field experiment.

Table 2. Temporal changes in atrazine and cyanazine concentrations in the North and South windrows following treatment with zerovalent iron, ferrous sulfate, and emulsified oil (EOS 598B42).

\begin{tabular}{|c|c|c|c|c|c|c|c|c|c|c|}
\hline \multirow{2}{*}{$\begin{array}{l}\text { Pesticide } \\
\text { (Windrow) }\end{array}$} & \multicolumn{10}{|c|}{ Time (d) } \\
\hline & Initial & 7 & 14 & 21 & 30 & 60 & 250 & 270 & 315 & $342+$ \\
\hline & & & & & $-\mathrm{mg} \mathrm{kg}$ & & & & & \\
\hline Atrazine (North) & $30.25(16.90) \neq$ & $15.94(7.18)$ & $12.45(7.08)$ & $11.23(5.50)$ & $8.91(5.71)$ & $7.14(2.70)$ & $4.81(3.28)$ & $4.67(2.77)$ & $3.86(3.80)$ & $2.80(1.14)$ \\
\hline Percent decrease & & 47.3 & 58.8 & 62.9 & 71.5 & 76.4 & 84.1 & 84.6 & 87.2 & 90.7 \\
\hline Atrazine (South) & $15.87(7.45)$ & $12.03(6.30)$ & $10.40(4.05)$ & $5.50(1.8)$ & $4.94(2.88)$ & $4.37(1.02)$ & $4.66(1.64)$ & $5.28(2.21)$ & $4.79(3.80)$ & $3.34(1.63)$ \\
\hline Percent decrease & & 24.2 & 34.5 & 65.3 & 68.9 & 72.4 & 70.6 & 66.7 & 69.8 & 79.0 \\
\hline Cyanazine (North) & $30.25(17.67)$ & $17.54(5.38)$ & $15.71(12.5)$ & $11.93(10.61)$ & $7.81(7.55)$ & $7.98(6.01)$ & $7.83(2.76)$ & $9.71(3.06)$ & $4.88(2.95)$ & $2.71(1.63)$ \\
\hline Percent decrease & & 42.0 & 48.1 & 60.6 & 74.2 & 73.6 & 74.1 & 67.9 & 83.9 & 91.0 \\
\hline Cyanazine (South) & $29.15(21.8)$ & $19.63(16.0)$ & $7.29(6.36)$ & $6.36(3.70)$ & $5.17(2.47)$ & $5.25(3.22)$ & $5.57(3.35)$ & $7.77(5.29)$ & $7.03(4.69)$ & $3.92(2.34)$ \\
\hline Percent decrease & & 32.7 & 75.0 & 78.2 & 82.3 & 82.0 & 80.9 & 73.3 & 75.9 & 86.6 \\
\hline
\end{tabular}

† Windrows were mechanically mixed on Day 342 before sampling.

‡ Parenthetic values represent sample standard deviation $(n=15-20)$. 
Initial analysis of the contaminated soil indicated that, in addition to atrazine and cyanazine, the mixed soil had very high concentrations of $\mathrm{NO}_{3}^{-}, \mathrm{NH}_{4}^{+}$, and $\mathrm{P}$ as well as diethylenetriaminepentaacetic acid (DTPA)-extractable metals ( $\mathrm{n}$, $\mathrm{Mn}, \mathrm{Fe}, \mathrm{Cu}$ ) (Table 1). Following $342 \mathrm{~d}$ of treatment, some notable changes in soil chemical properties were observed (Table 1). Extractable P concentrations decreased in the windrows following treatment. Iron salts have been used to efficiently remove P from wastewater (Zeng et al., 2004). Nitrate concentrations were reduced following $\mathrm{Fe}^{0}$ treatments, corroborating previous research showing transformation of $\mathrm{NO}_{3}^{-}$to $\mathrm{NH}_{4}^{+}$ on addition of $\mathrm{Fe}^{0}$ (Cheng et al., 1997; Till et al., 1998). The added $\mathrm{C}$ source also likely facilitated denitrification. Because most reductive reactions consume protons $\left(\mathrm{H}^{+}\right)$, anaerobic transformations have been shown to increase $\mathrm{pH}$ in acidic soils (Seybold et al., 2001). Iron corrosion also causes an increase in $\mathrm{pH}$. This was observed in our study where the initial $\mathrm{pH}$ of the contaminated soil increased from 5.5 to 7 within $60 \mathrm{~d}$. However production of organic acids and $\mathrm{CO}_{2}$ may contribute to soil acidity and cause $\mathrm{pH}$ to decrease (Patrick and DeLaune, 1977; Wang et al.,1993) which was seen at $315 \mathrm{~d}$ when $\mathrm{pH}$ again decreased to 5 over the winter months and then increased to 5.9 after the final mixing at $342 \mathrm{~d}$.

\section{Acknowledgments}

We thank Compliance Advisory Services (Hastings, NE) for technical assistance with field-scale treatment of contaminated soil. We also thank Dr. Gay Yuen for fungal identification. This research was supported by the UNL School of Natural Resources and the Nebraska Research Initiative through the Water Science Laboratory. This paper is a contribution of Agric. Res. Div. Project NEB-38-071.

\section{References}

Alowitz, M.J., and M.M. Scherer. 2002. Kinetics of nitrate, nitrite and Cr(VI) reduction by iron metal. Environ. Sci. Technol. 36:299-306.

Blowes, D.W., C.J. Ptacek, and J.L. Jambor. 1997. In-situ remediation of $\mathrm{Cr}$ (VI)-contaminated groundwater using permeable reactive walls: Laboratory studies. Environ. Sci. Technol. 31:3348-3357.

Cai, X., S. Guangyao, and L. Weiping. 2007. Degradation and detoxification of acetochlor in soils treated by organic and thiosulfate amendments. Chemosphere 66:286-292.

Cheng, I.F., R. Muftikian, Q. Fernando, and N. Korte. 1997. Reduction of nitrate to ammonia by zero-valent iron. Chemosphere 35:2689-2695.

Chiou, C.T., P.E. Porter, and D.W. Schmedding. 1983. Partition equilibria of nonionic organic compounds between soil organic matter and water. Environ. Sci. Technol. 17:227-231.

Comfort, S.D., P.J. Shea, T.A. Machacek, H. Gaber, and B.-T. Oh. 2001. Field scale remediation of metolachlor-contaminated spill site using zerovalent iron. J. Environ. Qual. 30:1636-1643.

Crawford, R.J., I.H. Harding, and D.E. Mainwaring. 1993. Adsorption and coprecipitation of single heavy metal ions onto the hydrated oxides of iron and chromium. Langmuir 9:3050-3056.

Gan, J.Y., and W.C. Koskinen. 1998. Pesticide fate and behavior in soil at elevated concentrations. p. 59-84. In P.C. Kearney and T. Roberts (ed.) Pesticide remediation in soil and water. John Wiley \& Sons, New York.

Gibb, C., T. Satapanajaru, S.D. Comfort, and P.J. Shea. 2004. Remediating dicamba-contaminated water with zerovalent iron. Chemosphere 54:841-848.

Grant, M.A., and F.D. Williams. 1982. Bacterial metabolism under conditions representing pesticide disposal pits. J. Environ. Sci. Health B17:393-407.

Gu, B., J. Schmitt, Z. Chen, L. Liang, and J.F. McCarthy. 1994. Adsorption and desorption of natural organic matter on iron oxide: Mechanisms, and models. Environ. Sci. Technol. 28:38-46.

Hoffman, M.R. 1990. Catalysis in aquatic environments. p. 71-111. In W. Stumm (ed.) Aquatic chemical kinetics. John Wiley \& Sons, New York.

Issa, S., and M. Wood. 2005. Degradation of atrazine and isoproturon in surface and sub-surface soil materials undergoing different moisture and aeration conditions. Pest Manage. Sci. 61:126-132.

McBride, M.B. 1994. Environmental chemistry of soils. Oxford Univ. Press, New York.

Minnesota Department of Agriculture. 1997. Results of 1996 soil sampling of pesticides on crop production retailer facilities. Agron. and Plant Protection Serv., St. Paul, MN.

Moorman, T.B., J.K. Cowan, E.L. Arthur, and J.R. Coats. 2001. Organic amendments to enhance herbicide biodegradation in contaminated soils. Biol. Fertil. Soils 33:541-545.

Park, J., S.D. Comfort, P.J. Shea, and T.A. Machacek. 2004. Remediating munitions-contaminated soil with zerovalent iron and cationic surfactants. J. Environ. Qual. 33:1305-1313.

Patrick, W.H., Jr., and R.D. DeLaune. 1977. Chemical and biological redox systems affecting nutrient availability in the coastal wetlands. Geosci. Man 18:131-137.

Powell, R.M., R.W. Puls, S.K. Hightower, and D.A. Sabatini. 1995. Coupled iron corrosion and chromate reduction: Mechanisms for subsurface remediation. Environ. Sci. Technol. 29:1913-1922.

Satapanajaru, T. 2002. Remediating chloroacetanilide-contaminated water using zerovalent iron. Ph.D. diss. Univ. of Nebraska, Lincoln (Diss. Abstr. Int., B 2003, 63(12), 5741).

Satapanajaru, T., S.D. Comfort, and P.J. Shea. 2003a. Enhancing metolachlor destruction rates with aluminum and iron salts during zerovalent iron treatment. J. Environ. Qual. 32:1726-1734.

Satapanajaru, T., P.J. Shea, S.D. Comfort, and Y. Roh. 2003b. Green rust and iron oxide formation influences metolachlor dechlorination during zerovalent iron treatment. Environ. Sci. Technol. 37:5219-5227.

Satoh, Y., K. Kikuchi, S. Kinoshita, and H. Sasaki. 2006. Potential capacity of coprecipitation of dissolved organic carbon (DOC) with iron(III) precipitates. Limnol. 7:231-235.

Seybold, C.A., W. Mersie, and C. McNamee. 2001. Anaerobic degradation of atrazine and metolachlor and metabolite formation in wetland soil and water microcosms. J. Environ. Qual. 30:1271-1277.

Shin, J.Y., and M.A. Cheney. 2004. Abiotic transformation of atrazine in aqueous suspension of four synthetic manganese oxides. Colloid Surf. 242:85-92.

Shin, J.Y., and M.A. Cheney. 2005. Abiotic dealkylation and hydrolysis of atrazine by birnessite. Environ. Toxicol. Chem. 24:1353-1360.

Singh, J., S.D. Comfort, and P.J. Shea. 1998a. Remediating RDX-contaminated water and soil using zero-valent iron. J. Environ. Qual. 27:1240-1245.

Singh, J., P.J. Shea, L.S. Hudal, S.D. Comfort, T.C. Zhang, and D.S. Hage. 1998 b. Iron-enhanced remediation of water and soil containing atrazine. Weed Sci. 46:281-388.

Till, B.A., L.J. Weathers, and P.J. Alvarez. 1998. Fe(0)-supported autotrophic denitrification. Environ. Sci. Technol. 32:634-639.

USEPA. 1999. Pesticide industry sales and usage report. U.S. Environmental Protection Agency, Washington, DC.

Wagner, S.C., and R.M. Zablotowicz. 1997. Effect of organic amendments on the bioremediation of cyanazine and fluometron in soil. J. Environ. Sci. Health B32:37-54.

Wang, Z.P., R.D. DeLaune, P.H. Masscheleyn, and W.H. Patrick, Jr. 1993. Soil redox and $\mathrm{pH}$ effects on methane production in a flooded rice soil. Soil Sci. Soc. Am. J. 57:382-385.

Zeng, L., X. Li, and J. Liu. 2004. Adsorptive removal of phosphorous from aqueous solution using iron oxide tailings. Water Res. 38:1318-1326. 